\title{
O AGRAVO INTERNO NO CPC/2015 E SUA RELAÇÃO COM AS TÉCNICAS DO DISTINGUISHING E OVERRULING ${ }^{1}$
}

THE INTERNAL INTERLOCUTORY APPEAL IN THE BRAZILIAN CIVIL PROCEDURE CODE OF 2015 AND ITS RELATION WITH TECHNIQUES OF THE DISTINGUISHING AND OVERRULING

Guilherme César Pinheiro

Doutorando e Mestre em Direito Processual pela Pontifícia Universidade Católica de Minas Gerais. Professor de Direito Processual Civil e Direito Civil das Faculdades Santo Agostinho, unidade de Sete Lagoas/MG. Sete Lagoas/MG. Advogado. E-mail: guilhermepinheiroadv@hotmail.com

RESUMO: Este artigo pretende discutir a relevância que o recurso de agravo interno adquiriu no Novo CPC na hipótese de interposição contra decisão monocrática (unipessoal) que aprecia o mérito do recurso (art. 932, IV e V), dando-lhe ou negando-lhe provimento, com fundamento na existência de precedente vinculante (art. 927) sobre a matéria tratada nas razões recursais ou na decisão recorrida. A questão que se coloca é que o recurso não pode ser compreendido apenas como um meio de técnico que a parte manifesta seu inconformismo com a decisão, mas sim como direito constitucional, decorrente do contraditório e da ampla defesa, criador de um espaço procedimental discursivo e viabilizador de correção normativa e legitimidade das decisões judiciais. A partir disso é que se visa a chamar atenção para a relação do agravo interno com as técnicas do distinguishing e overruling, que são essenciais para que o recorrente obtenha êxito em seu recurso.

\footnotetext{
${ }^{1}$ Artigo recebido em 22/01/2019 e aprovado em 18/08/2019.
} 
Revista Eletrônica de Direito Processual - REDP.

Rio de Janeiro. Ano 13. Volume 20. Número 3. Setembro a Dezembro de 2019

Periódico Quadrimestral da Pós-Graduação Stricto Sensu em Direito Processual da UERJ

Patrono: José Carlos Barbosa Moreira (in mem.). ISSN 1982-7636. pp. 187-215

www.redp.uerj.br

PALAVRAS-CHAVE: Direito ao Recurso, Distinguishing e Overruling, Correção Normativa.

ABSTRACT: This article intends to discuss the relevance that the Internal Interlocutory Appeal acquired in the New CPC, in the hypothesis of interposition against a monocratic (one-person) decision that appreciates the merits of the Appeal (article 932, IV and V), giving or denying it, on the basis of the existence of a legally binding precedent (Article 927) on the subject-matter of the appeal or the appealed decision. The question that arises is that the resource cannot be understood only as a means of technician that the parts manifests its nonconformity with a decision, but rather as constitutional right, resulting from the contradictory and ample defense, creator of a procedural space discursive and feasible of normative correctness and legitimacy of the judicial decisions. From this, it aims to draw attention to the relations Internal Interlocutory Appeal with the techniques of distinguishing and overruling, which are essential for the appellant to succeed in his appeal.

KEY WORDS: Right to Appeal, Distinguishing and Overruling, Normative Correctness.

\section{INTRODUÇÃO}

O sistema recursal brasileiro foi bastante alterado pelo CPC/2015, sendo inclusive, o assunto que sofreu as modificações mais significativas. Tanto é que a Lei 12.526/2016 alterou a sistemática recursal no período de vacatio legis do CPC/2015, especialmente no que diz respeito ao juízo de admissibilidade dos recursos extraordinários.

Em razão disso, os estudiosos do Direito Processual têm se debruçado sobre as principais inovações trazidas pelo CPC/2015 no que tange aos recursos. Muito se tem escrito acerca da inibição da conhecida "jurisprudência defensiva" pela norma fundamental da primazia do mérito (art. $4^{\circ}$ ); a relação das decisões interlocutórias não agraváveis e o recurso de apelação tem chamado atenção dos processualistas; os problemas atinentes à recorribilidade das decisões interlocutórias e a nova regulamentação do agravo de instrumento, de igual maneira, é assunto sempre presente em textos científicos; as 
Revista Eletrônica de Direito Processual - REDP.

Rio de Janeiro. Ano 13. Volume 20. Número 3. Setembro a Dezembro de 2019

Periódico Quadrimestral da Pós-Graduação Stricto Sensu em Direito Processual da UERJ

Patrono: José Carlos Barbosa Moreira (in mem.). ISSN 1982-7636. pp. 187-215 www.redp.uerj.br

inovações acerca da recorribilidade repetitiva e nos recursos extraordinários despertam grande interesse dos juristas.

Não há dúvida de que esses e outros temas pertinentes aos recursos no processo civil são relevantíssimos e merecem incessantes e profundos estudos. Todavia, o recurso de agravo interno não tem sido objeto de muita pesquisa por partes dos estudiosos do Direito Processual. Ao que parece a importância que tal recurso tem para o atual sistema ainda não foi percebida pela comunidade científica.

Em face disso, a partir das noções do processo constitucional como metodologia de garantia de direitos fundamentais ${ }^{2}$ e do processualismo constitucional democrático, fundado sobremaneira na ideia de policentrismo processual ${ }^{3}$, este artigo pretende ressaltar a relevância que o agravo interno tem para o atual sistema processual brasileiro, máxime no que se refere ao controle e à aplicação discursiva dos pronunciamentos decisórios vinculantes ou precedentes obrigatórios (art. 927 do CPC/2015), por meio das técnicas do distinguishing e do overruling. Isso pelo fato de que nos dias atuais é perceptível grande concentração de poderes nas mãos dos relatores e um considerável número de decisões monocráticas que são proferidas ${ }^{4}$.

Ademais, o artigo 932 do CPC/2015 - matriz normativa das decisões monocráticas (unipessoais) - autoriza, em seus incisos IV e V, que relator aprecie monocraticamente o mérito do recurso quando houver pronunciamento decisório vinculante dos tribunais superiores ou precedente judicial obrigatório a respeito da matéria tratada pelo recurso ou pela decisão recorrida.

Para tanto, num primeiro momento, necessário propor noção básica de recurso que o CPC/2015 reclama, considerando as mudanças paradigmáticas trazidas pelo novel diploma processual. Igualmente, torna-se mister sublinhar o relevo que os recursos

\footnotetext{
${ }^{2}$ BARACHO, José Alfredo de Oliveira. Teoria geral do processo constitucional. Revista da Faculdade Mineira de Direito, Belo Horizonte, v. 2, n. 3 e 4, p. 89-154, $1^{\circ}$ e $2^{\circ}$ sem. 1999; BARACHO, José Alfredo de Oliveira. Direito processual constitucional: aspectos contemporâneos. Belo Horizonte: Fórum, 2008; BRÊTAS C. DIAS, Ronaldo. Processo constitucional e estado democrático de direito. $4^{\text {a }}$ Edição Belo Horizonte: Del Rey. 2018.

${ }^{3}$ NUNES, Dierle José Coelho. Processo jurisdicional democrático: uma análise crítica das reformas processuais. Curitiba: Juruá, 2009.

${ }^{4}$ Dierle José Coelho Nunes analisou relatório estatístico do Superior Tribunal de Justiça do ano de 2014 e demonstra que no referido ano foram proferidas 308.405 decisões monocráticas e 81.647 decisões colegiadas (NUNES, Dierle José Coelho. Colegialidade Corretiva e CPC-2015. In: Fredie Didier Jr., Lucas Buril de Macêdo, Ravi Peixoto, Alexandre Freire. (Org.). Coleção Novo CPC - Doutrina Selecionada - processos nos tribunais e meios de impugnação às decisões judiciais. 2ed.Salvador: Jus Podivm, 2016, v. 6 p. 34-35).
} 
Rio de Janeiro. Ano 13. Volume 20. Número 3. Setembro a Dezembro de 2019

Periódico Quadrimestral da Pós-Graduação Stricto Sensu em Direito Processual da UERJ

Patrono: José Carlos Barbosa Moreira (in mem.). ISSN 1982-7636. pp. 187-215 www.redp.uerj.br

adquiriram nos últimos anos, sobretudo no que diz respeito à construção, ao controle e à aplicação de pronunciamento decisórios vinculantes ou precedentes obrigatórios.

Em seguida, mostra-se indispensável fazer breve percurso histórico-legislativo acerca da tendência de valorização de julgados dos tribunais superiores, com a qual se pretende criar uma vinculação decisória e aproximar-se do sistema de precedentes judiciais do common law.

Após essa parte introdutória, será dedicado um tópico para tratar do agravo interno e sua relação com a aplicação dos provimentos jurisdicionais vinculantes (art. 927) dos tribunais superiores, na perspectiva de um processo discursivo, que não aniquile o direito das partes de construírem comparticipadamente as decisões que produzirão efeitos sobre suas esferas jurídicas. E mais: esse processo discursivo também deve possibilitar às partes o controle da criação e a aplicação dos referidos pronunciamentos vinculantes ou precedentes obrigatórios.

Ao final, espera-se contribuir, de maneira propedêutica, com os estudos sobre o sistema recursal regulado pelo $\mathrm{CPC} / 2015$ e sua estreia relação com as técnicas do distinguishing e do overruling, a partir de uma proposta de compreensão do direito constitucional ao recurso fundamentado na pretensão de correção normativa das decisões judiciais e a consequente legitimidade do exercício da atividade jurisdicional.

\section{RECURSO COMO DIREITO CONSTITUCIONAL GARANTIDOR DA POSSIBILIDADE DE CORREÇÃO NORMATIVA E LEGITIMIDADE DA DECISÃO RECORRIDA}

Ao se iniciar o estudo sobre recursos, não é difícil encontrar manuais de enorme aceitação acadêmica ligando o instituto do recurso à insatisfação e ao inconformismo psicológicos, inerentes aos seres humanos, contra decisões que lhes forem desfavoráveis. Em síntese, fundamenta-se o recurso na necessidade de o ser humano manifestar sua irresignação com o conteúdo decisório adverso aos seus interesses fático-jurídicos. Veja, por exemplo, o que escreve Araken de Assis acerca do conceito e fundamento do instituto do recurso: 
"O inconformismo arrebata homens e mulheres nas situações incômodas e desfavoráveis. Pouco aquiescem passivamente à adversidade. Envolvendo a rotina da condição humana conflitos intersubjetivos, resolvidos por intermédio da intervenção do Estado, a vida em sociedade se transforma em grandiosa fonte de incômodos. E a própria pendência do mecanismo instituído para equacionar os conflitos provoca dissabores de outra natureza. A causa mais expressiva do descontentamento, cumulada à sensação asfixiante de desperdício de tempo valioso, avulta nos pronunciamentos contrários ao interesse das partes e de terceiros emitidos neste âmbito. O homem e a mulher na sociedade pós-moderna se acostumaram às relações instantâneas dos modernos meios de comunicação e reagem muito mal a qualquer demora e a soluções que não lhes atendam plena e integralmente os interesses. $\mathrm{O}$ escoadouro do inconformismo insopitável e, ao mesmo tempo, meio para reparar, tanto quanto possível, os erros inerentes à falibilidade, porque a base desses pronunciamentos, originários do marco civilizatório chamado processo, assenta num juízo singular ou coletivo de homens e mulheres, só pode ser a impugnação do ato estatal"s.

Atento a esse panorama, André Cordeiro Leal, em abordagem muito interessante, aponta que fundamentar o direito de recorrer num natural inconformismo do ser humano a tudo que lhe é adverso é mítico e supõe a (persistente) influência dos escritos de Oskar Von Bülow no Direito Processual ${ }^{6}$, de modo que o recurso é tradicionalmente trabalhado pela processualística como "ato desesperado (ou esperançoso) de delinquentes-litigantescontumazes, a ser admitido, após vigilantes filtragens sucessivas, pelo Estado-juiz, ainda supõe o direito processual e a jurisdição bülowianos e é, não raro, uma espécie de válvula de escape para uma afirmada "natural' irresignação do ser humano"7.

Contudo, importa salientar que o CPC/2015 está inserido num contexto de constitucionalização do Direito brasileiro e redemocratização da sociedade e do Estado, devido à promulgação da Constituição de 1988 e a instituição do Estado Democrático de Direito $^{8}$. Assim, os institutos presentes no CPC/2015 precisam ser compreendidos a partir

\footnotetext{
${ }^{5}$ Manual dos Recursos. 6a . ed. São Paulo: Editora Revista dos Tribunais, 2014, p. 43.

${ }^{6}$ Mais sobre a influência da teoria de Bülow no Direito Processual, consultar LEAL, André Cordeiro. Instrumentalidade do processo em crise. Belo Horizonte: Mandamentos, 2008.

${ }^{7}$ LEAL, André Cordeiro. Inconsistências do direito ao recurso como meio de acesso ao duplo grau de jurisdição. In: CASTRO, João Antônio de Lima; FREITAS, Sérgio Henriques Zandona. (Org.). Direito Processual - Estudo da Processualidade Jurídica Constitucionalizada. 1ed.Belo Horizonte: PUC MINAS Instituto de Educação Continuada, 2012, p. 337-338.

${ }^{8}$ Estudiosos do tema reformas processuais apontam a existência de dois motes reformistas: reformas pontuais (microestruturais) e reformas globais (macroestruturais). O primeiro ocorreu, no Brasil, no início da década de 1990, cuja a principal finalidade foi adequar, de maneira emergencial, à Constituição aqueles dispositivos constantes na legislação processual que se mostravam mais críticos em relação à nova ordem constitucional. E, com isso, refletiram um momento político de redemocratização e construção de um novo projeto para a
} 
Revista Eletrônica de Direito Processual - REDP.

Rio de Janeiro. Ano 13. Volume 20. Número 3. Setembro a Dezembro de 2019

Periódico Quadrimestral da Pós-Graduação Stricto Sensu em Direito Processual da UERJ

Patrono: José Carlos Barbosa Moreira (in mem.). ISSN 1982-7636. pp. 187-215

www.redp.uerj.br

do constitucionalismo democrático, de sorte que não se mostra adequado continuar compreendendo e interpretando as disposições normativas e institutos do CPC/2015 com os olhos presos a marcos científicos do passado.

Nesse marco teórico, o CPC/2015 é muito mais do que uma nova legislação processual que busca imprimir maior unidade e sistematicidade ao sistema processual, que regulamentou novos institutos (incidentes de resolução de demandas repetitivas, amicus curiae, normas fundamentais, só para citar três) e extirpou outros (agravo retido, embargos infringentes, nomeação à autoria, são alguns exemplos). O propósito do CPC/2015 é implementar nova racionalidade da prática de aplicação do Direito, é mudar paradigmaticamente na compreensão de institutos do Direito Processual brasileiro.

Com isso, não se pode mais limitar a compreensão de que recursos são meios técnicos pelos quais as partes, o Ministério Público e terceiros interessados manifestam insatisfação ou inconformismo com a decisão que lhe foi juridicamente desfavorável. De igual maneira, recurso não pode ficar vinculado apenas ao acesso ao duplo grau de jurisdição, como se apenas a possibilidade legal de recorrer de determinada decisão atendesse a exigência de correção normativo-constitucional e legitimidade do exercício da atividade jurisdicional no Estado Democrático de Direito.

Esse novo panorama normativo exige que o recurso seja compreendido como direito constitucional (art. $5^{\circ}, \mathrm{LV}$ da Constituição brasileira) garantidor da possibilidade de correção normativa das decisões judiciais, a partir de espaço procedimental discursivo, criado pelo contraditório e pela ampla defesa, que possibilita a revisibilidade dos atos decisórios recorríveis por meio do apontamento das falibilidades de seus conteúdos, que no

sociedade brasileira. O CPC de 1973 foi pródigo no assunto, pois, segundo Ronaldo Brêtas de Carvalho Dias, durante os 43 anos de vigência do referido código, ocorreram aproximadamente 500 alterações, por meio de cerca de 50 leis (BRÊTAS C. DIAS, Ronaldo. As reformas do Código de Processo Civil e o modelo constitucional do processo. In: BRÊTAS C. DIAS, Ronaldo; NEPOMUCENO, Luciana Diniz (Org.). Processo Civil Reformado. $2^{a}$ ed. Belo Horizonte: Del Rey, 2009, p. 457-496). Acontece que as reformas pontuais trazem consigo, inevitavelmente, um problema: transformam o código numa colcha de retalhos, fato que prejudica a necessária coesão sistemática de um código de processo. O foco, porém, das reformas globais ou macroestruturais é diferente, porque agora adota-se como ponto de partida a Constituição, com todos os seus avanços e retrocessos nas suas três décadas de vigência, para a construção de uma lei federal adequada aos postulados democráticos. (BARROS, Flaviane de Magalhães; NUNES, Dierle José Coelho. As reformas processuais macroestruturais brasileiras. In: BARROS, Flaviane de Magalhães; BOLZAN DE MORAIS, José Luis. (Org.). Reforma do processo civil: perspectivas constitucionais. Belo Horizonte: Fórum, 2010, p. 17-28; BARROS, Flaviane de Magalhães.; NUNES, Dierle José Coelho. Macro-strutural procedural reforms in Brazil. Revista da Faculdade de Direito do Sul de Minas, v. 26, p. 7-40, 2010; PINHEIRO, Guilherme César; SANTOS JUNIOR, Waldir Miguel. O princípio constitucional da presunção de inocência e o Projeto de Novo Código de Processo Penal. Revista eletrônica de direito processual, v. 18, p. 175-197, 2017). 
Revista Eletrônica de Direito Processual - REDP.

Rio de Janeiro. Ano 13. Volume 20. Número 3. Setembro a Dezembro de 2019

Periódico Quadrimestral da Pós-Graduação Stricto Sensu em Direito Processual da UERJ

Patrono: José Carlos Barbosa Moreira (in mem.). ISSN 1982-7636. pp. 187-215 www.redp.uerj.br

direito processual recebem a designação de erros jurídicos - error in procedendo e error in iudicando ${ }^{9}$. É esse espaço procedimental discursivo, viabilizado pelo contraditório e pela ampla defesa, que propicia a correção normativa e o alcance da legitimidade decisória e do exercício da atividade jurisdicional.

Nesse sentido, Dierle Nunes compreende que o instituto do recurso é

"[...]criador de um espaço procedimental discursivo de ataque das falibilidades do sistema processual, que é imperfeito e nem sempre garante contraditório dinâmico e uma ampla defesa preventiva, passando a ser um corolário ineliminável destas garantias constitucionais, possibilitando o seu exercício de maneira sucessiva e a comparticipação dos sujeitos processuais em todos os provimentos, constituindo um instrumento decorrente de nosso modelo constitucional de processo"10.

No caso específico do agravo interno, o CPC/2015 (art. $1.021 \S 1^{\circ}$ ) deixa bem claro a exigência de que impugnação específica dos fundamentos da decisão recorrida. Isto é, ônus da dialeticidade recursal é requisito de admissibilidade do recurso em questão e exige do recorrente esforço argumentativo e cooperativo no sentido de indicar os erros constantes na decisão monocrática recorrida. Veda-se com isso a mera repetição de razões recursais de recurso anterior ou qualquer outra petição que tenha ensejado a decisão monocrática impugnada.

A legislação processual ressalta essa exigência de impugnação específica pela circunstância de que o agravo interno na prática forense brasileira sempre foi comumente utilizado de modo automatizado, generalizado, acrítico, quase que como uma burocracia

\footnotetext{
${ }^{9}$ A teoria dos recursos divide os erros judiciários em dois grupos com consequências diferentes: error in procedendo e error in judicando. O primeiro é caracterizado pela equivocada aplicação de normas de direito processual. É o caso de inobservância das normas referentes às formas e aos modos de atuação da atividade jurisdição. Por exemplo, quando a citação do réu não é realizada conforme determina o CPC, ou quando o juiz indefere a produção de uma prova necessária e cerceia a defesa de uma das partes. Nesses casos, ao se constatar a existência de error in procedendo, a consequência jurídica que se impõe é anulação (cassação) da decisão recorrida, determinando-se que o juízo a quo profira outra decisão. Por outro lado, pode haver também error in judicando quando se estiver diante de errônea aplicação de normas de direito material prima facie aplicáveis ao caso, inadequada apreciação dos fatos e provas discutidos no processo. Quando o conteúdo da decisão se mostrar desconforme ao preceituado pelo ordenamento jurídico vigente, ou tenha havido equívoco na apreciação dos fatos e provas constantes nos autos e construídos em contraditórios pelas partes, a consequência jurídica do provimento (acatamento) do recurso é diversa da constatação do error in procedendo, eis que o juízo ad quem proferirá uma decisão que substituirá a recorrida no que tiver sido objeto. Haverá a modificação ou reforma da decisão recorrida e não sua anulação. (BRÊTAS C. DIAS, Ronaldo; SOARES, Carlos Henrique; MARQUES BRÊTAS, Suzana Oliveira; DIAS, Renato José Barbosa; BRÊTAS Yvonne Mól. Estudo Sistemático do NCPC. $2^{\mathrm{a}}$ ed. D’PLÁCIO Editora. Belo Horizonte 2016, p. 187-188.).

10 Direito constitucional ao recurso: da teoria geral dos recursos, das reformas processuais e da comparticipação nas decisões. Rio de Janeiro: Lumen Juris, 2006, p. 177.
} 
Revista Eletrônica de Direito Processual - REDP.

Rio de Janeiro. Ano 13. Volume 20. Número 3. Setembro a Dezembro de 2019

Periódico Quadrimestral da Pós-Graduação Stricto Sensu em Direito Processual da UERJ

Patrono: José Carlos Barbosa Moreira (in mem.). ISSN 1982-7636. pp. 187-215 www.redp.uerj.br

essencial do procedimento. Ou seja, sempre que se estava diante de uma decisão monocrática interpunha-se agravo interno, apenas para fazer com a questão resolvida unipessoalmente fosse reapreciada pelo colegiado. Tal fato ocorre ou ocorria, ainda, pela necessidade de esgotamento das vias ordinárias para eventual interposição de recursos especial e/ou extraordinários ou até mesmo pelo aumento dos poderes dos relatores. Acontece que a interposição generalizada de agravo interno acabou por gerar a prática de falsas ou insatisfatórias apreciações de tais recursos com meras repetições do que fora exposto pelo relator da decisão monocrática ${ }^{11}$, fato de que nem de longe atende às exigências de correção normativa e legitimidade do exercício da atividade jurisdicional do Estado Democrático de Direito.

Importa frisar que a correção normativa e a legitimidade do exercício da atividade jurisdicional que se almeja com essa noção de recurso em nada se relaciona com uma exigência de proferimento de "decisões justas" pelo seu conteúdo moral, ético, axiológico ou pragmático, eis que elas implicam sobrecarga argumentativa aos sujeitos processuais, sobretudo aos magistrados, que, muitas vezes, são considerados como portadores de um "inacessível privilégio cognitivo", o que é reforçado e facilitado quando não se faz uma distinção entre os discursos de justificação e aplicação do Direito ${ }^{12}$.

Quando se fala em decisões corretas e legitimadas, quer se referir àquelas que decorrem dos argumentos trazidos ao processo pelos sujeitos processuais. De modo que o processo se constitua num espaço procedimental discursivo e cooperativo de problematização de questões fáticas e jurídicas, traduzidas em pretensões e resistências articuladas pelas partes. Essas decisões necessitam mostrar-se, ao mesmo tempo, em consonância com o ordenamento jurídico vigente, respeito à legalidade.

As palavras de Marcelo Andrade Cattoni de Oliveira acerca da legitimidade das decisões judiciais são esclarecedoras e merecerem transcrição:

\footnotetext{
${ }^{11}$ MACÊDO, Lucas Buril. Agravo interno: análise das modificações legais e de sua recepção no Superior Tribunal de Justiça. Revista de Processo (RePro) vol. 269, 2017, p. 314-314. Ver também interessante texto de Dierle Nunes e Antônio Aurélio de Souza Viana, no qual os autores, valendo-se do texto de Lucas Buril de Macêdo, alertam para o surgimento de uma nova jurisprudência defensiva no âmbito no STJ ( NUNES, Dierle José Coelho ; VIANA, Antônio Aurélio de Souza. . Ônus da dialeticidade: nova 'jurisprudência defensiva' no STJ? Consultor Jurídico (Conjur) (SÃO PAULO. ONLINE), v. 15052017, 2017, p. 1-5).

${ }^{12}$ A respeito da distinção entre discurso de justificação e aplicação do Direito, ver (PINHEIRO, Guilherme César. A vinculação decisória no Estado Democrático de Direito: por uma compreensão constitucionalmente adequada da aplicação de precedentes, súmulas e decisões vinculantes. Rio de Janeiro: Lumen Juris. 2016, p. 112-129 e 212-225).
} 
"Há muito a questão acerca da legitimidade das decisões jurisdicionais deixou de ser um problema que se reduza tão somente à pessoa do juiz, à sua virtude ou à sua forma de seleção, ou a um momento quase mítico de tomada de decisão. O que garante a legitimidade das decisões é, antes, direitos e garantias fundamentais, de caráter processual, atribuídas às partes e que são, principalmente, os do contraditório e da ampla defesa (Constituição da República, art. $5^{\circ}, \mathrm{LV}$ ) além da necessidade racional de fundamentação das decisões (Constituição da República, art. 93, IX). Embora o Direito diga respeito a todos os cidadãos, nos discursos de aplicação, essa necessidade de legitimidade afeta diretamente àqueles que sofrerão os efeitos do provimento jurisdiciona" ${ }^{\prime 3}$.

Dessa forma, não se interpõe recurso apenas para expressar a insatisfação pessoal e psicológica contra o conteúdo do ato decisório que lhe é adverso. Tanto é que se exige do recorrente a apresentação de razões impugnando especificamente os fundamentos da decisão recorrida. Isto é, indispensável sejam indicados os erros jurídicos da decisão recorrida e apresentadas razões fático-jurídicas para a sua correção normativa e o consequente provimento do recurso.

Portanto, o recurso se constitui num direito constitucional que visa (e possibilita) a garantir às partes, aos terceiros interessados e ao Ministério Público a correção normativa e a legitimidade das decisões judiciais e do exercício da atividade jurisdicional.

Essa questão parece ter ficado mais clara com a vigência do CPC/2015, notadamente depois da decisão da Primeira Turma do Supremo Tribunal Federal que afirmou que o prazo de cinco dias previsto no parágrafo único do artigo 932 CPC/2015 só se aplica aos casos em que seja necessário sanar vícios formais, como ausência de procuração ou de assinatura, e não à complementação da fundamentação. Na oportunidade, o ministro Marco Aurélio considerou que, se se admitisse a aplicação do mencionado dispositivo legal para os casos de recursos interposto sem impugnação específica dos fundamentos da decisão recorrida, de modo a impor aos relatores o dever de intimar o recorrente para sanar tal vício e indicar-lhe precisamente o vício a ser sanado, os relatores prestariam serviço de assessoramento aos advogados dos recorrentes, fato que foge à razoabilidade.

Outra perspectiva que urge ser afastada com o CPC/2015 é a relação do direito constitucional ao recurso com a acessibilidade ao duplo grau de jurisdição. É que, não raro,

\footnotetext{
${ }^{13}$ Processo Constitucional. 3. ed. Belo Horizonte: Editora Fórum, 2016, p.152.
} 
Rio de Janeiro. Ano 13. Volume 20. Número 3. Setembro a Dezembro de 2019

Periódico Quadrimestral da Pós-Graduação Stricto Sensu em Direito Processual da UERJ

Patrono: José Carlos Barbosa Moreira (in mem.). ISSN 1982-7636. pp. 187-215 www.redp.uerj.br

se depara com escritos que ligam o direito constitucional ao recurso ao duplo grau de jurisdição, este acessível pelo ato de recorrer. E a ligação que se faz é no sentido de que a simples possibilidade de recorrer da decisão propiciaria maior correção normativa (“justiça") na aplicação do Direito, principalmente pela circunstância de que os recursos são apreciados por órgãos colegiados, compostos por magistrados mais experientes e em alguns casos portadores de notório saber jurídico ${ }^{14}$.

Soma-se a isso as colocações de Dierle Nunes, que se mostram bastante proveitosas e merecem transcrição:

"[...] o instituto do recurso não pode ser analisado de modo unitário com o princípio do duplo grau de jurisdição, que duplo exame de todas as questões debatidas em juízo, mas sim deve ser visto como uma decorrência do princípio do contraditório e o da ampla defesa, possibilitando uma intervenção das partes e um diálogo destas com o juízo todas as vezes que a decisão recorrida não tenha levado em consideração seu conteúdo crítico"15.

No Estado Democrático de Direito, é inaceitável o fato de que a mera possibilidade de recorrer e, com isso, acessar o duplo grau de jurisdição confira correção normativa à decisão e legitimidade à jurisdição. Se o procedimento do recurso e seu ato de apreciação não representarem efetivamente a correção normativa da decisão e maior participação das partes na construção dos fundamentos decisórios, o duplo grau de jurisdição, que é acessível pelo direito de recorrer, não atenderá os postulados do constitucionalismo democrático. Ou seja, se a apreciação de recursos, expresso sobremaneira em acórdãos, continuar sendo um ato de julgar solitário e discricionário por um conjunto (colegiado) de especialistas que sequer dialogam entre si, não adianta ofertar duplo, triplo, quádruplo ou até mesmo décuplo grau de jurisdição pela interposição de sucessivos recursos. Se a jurisdição continuar sendo discricionária não adianta multiplicar o número de atos que expressam seu exercício arbitrário ou ampliar o número de julgadores do órgão colegiado, como determina a norma do art. 942 do CPC/2015.

\footnotetext{
${ }^{14}$ A respeito, em tom crítico, consultar LEAL, André Cordeiro. Inconsistências do direito ao recurso como meio de acesso ao duplo grau de jurisdição. In: CASTRO, João Antônio de Lima; FREITAS, Sérgio Henriques Zandona. (Org.). Direito Processual - Estudo da Processualidade Jurídica Constitucionalizada. 1ed.Belo Horizonte: PUC MINAS - Instituto de Educação Continuada, 2012, p. 342.

${ }^{15}$ NUNES, Dierle José Coelho. Direito constitucional ao recurso: da teoria geral dos recursos, das reformas processuais e da comparticipação nas decisões. Rio de Janeiro: Lumen Juris, 2006, p. 163.
} 
Rio de Janeiro. Ano 13. Volume 20. Número 3. Setembro a Dezembro de 2019

Periódico Quadrimestral da Pós-Graduação Stricto Sensu em Direito Processual da UERJ

Patrono: José Carlos Barbosa Moreira (in mem.). ISSN 1982-7636. pp. 187-215 www.redp.uerj.br

Em complemento, atualmente, é muito importante perceber que os recursos não se prestam apenas a impugnar decisões judiciais, eis que o sistema processual civil atribui excessiva valorização às decisões dos tribunais e determina observância obrigatória a algumas delas, de sorte que os recursos se apresentam, também, como mecanismo de construção e fiscalização das decisões que servirão de base para solução de uma infinidade de outros casos - pronunciamentos decisórios vinculantes ou precedentes obrigatórios ${ }^{16}$.

\section{UM BREVE PERCURSO HISTÓRICO-LEGISLATIVO SOBRE A TENDÊNCIA DO DIREITO BRASILEIRO DE VINCULAÇÃO DECISÓRIA POR JULGADOS DOS TRIBUNAIS SUPERIORES}

O Direito brasileiro, filiado ao civil law, tem atribuído acentuada importância à jurisprudência dos tribunais, por intermédio de criação de pronunciamentos decisórios vinculantes ou precedentes obrigatórios, os quais são utilizados como base decisória ou fonte de Direito, circunstância que o aproxima do common law. ${ }^{17}$

Tal valorização de algumas decisões dos tribunais superiores é perceptível ao se analisar algumas alterações legislativas que vem ocorrendo desde o ano de 1993, com a emenda à Constituição $\mathrm{n}^{\circ}$ 03, quando se estabeleceu que as decisões do controle concentrado de constitucionalidade das leis - ação de declaração de constitucionalidade ou inconstitucionalidade - teriam eficácia e efeitos obrigatórios em relação aos demais órgãos do Judiciário e do Executivo, no âmbito federal, estadual ou municipal. Ainda na década de noventa, a Lei de $\mathrm{n}^{\circ}$ 9.756/98 alterou as redações dos artigos 481, parágrafo único, e 557, caput e $\S 1^{\circ}$, ambos do Código de Processo Civil de 1973, e criou a possibilidade de o relator não conhecer de recursos que impugnassem decisões cujo conteúdo estivesse conforme jurisprudência dominante ou enunciado sumular do Tribunal correspondente. Ademais, instituiu a possibilidade de o relator, monocraticamente, dar provimento ao recurso compatível com a jurisprudência do Supremo Tribunal Federal ou de Tribunal Superior, além de liberar os órgãos fracionários de submeter a arguição de

\footnotetext{
${ }^{16}$ NUNES, Dierle José Coelho. Colegialidade Corretiva e CPC-2015. In: Fredie Didier Jr., Lucas Buril de Macêdo, Ravi Peixoto, Alexandre Freire. (Org.). Coleção Novo CPC - Doutrina Selecionada - processos nos tribunais e meios de impugnação às decisões judiciais. 2ed.Salvador: Jus Podivm, 2016, v. 6.

${ }^{17}$ Mais sobre o assunto, conferir PINHEIRO, Guilherme César. A vinculação decisória no Estado Democrático de Direito: por uma compreensão constitucionalmente adequada da aplicação de precedentes, súmulas e decisões vinculantes. Rio de Janeiro: Lumen Juris. 2016, p. 17-57).
} 
Rio de Janeiro. Ano 13. Volume 20. Número 3. Setembro a Dezembro de 2019

Periódico Quadrimestral da Pós-Graduação Stricto Sensu em Direito Processual da UERJ

Patrono: José Carlos Barbosa Moreira (in mem.). ISSN 1982-7636. pp. 187-215 www.redp.uerj.br

inconstitucionalidade ao plenário, na hipótese de existência de pronunciamento do Supremo ou do próprio tribunal acerca da questão objeto da mencionada arguição. Em seguida, as Leis de $\mathrm{n}^{\circ} 9.868$ e $\mathrm{n}^{\circ}$ 9882, ambas do ano de 1999 , trataram do procedimento de controle concentrado (ações diretas de constitucionalidade e inconstitucionalidade), assim como, da arguição de descumprimento de preceito fundamental, respectivamente, conferindo às decisões dessa última a mesma eficácia dos pronunciamentos decisórios da ação direta de constitucionalidade. Mas as modificações no ordenamento jurídico não pararam por aí: a Lei $\mathrm{n}^{\circ}$ 10. 352/2001 dispensou a remessa obrigatória ao tribunal, em decisões, contrárias aos interesses das Pessoas Jurídicas de Direito Público, cujo conteúdo estiver em conformidade com a jurisprudência do plenário do Supremo Tribunal Federal ou com enunciado sumular deste, ou tribunal superior competente (artigo $475 \S 3^{\circ} \mathrm{CPC}$ 1973). Em 2004 veio a emenda à Constituição n ${ }^{\circ} 45$, que criou o instituto da súmula vinculante. Após, a Lei 11.418/2006 estabeleceu que haverá repercussão geral, sempre quando o acórdão objeto de Recurso Extraordinário contrariar preceitos sumulados ou jurisprudência dominante do Supremo Tribunal Federal (543-A § $3^{\circ}$ CPC-1973). Esse mesmo ato normativo criou o instituto de Recursos Repetitivos, pelo qual em caso de questões idênticas que impliquem multiplicidade de recursos com pretensão isofórmica, o tribunal escolherá um ou mais recursos, paradigma para ser julgado e seu resultado será estendido àqueles sobrestados, declarando-os prejudicados, ou determinar que o tribunal $a$ quo se retrate da sua decisão - artigo 543-B CPC-1973 ${ }^{18}$.

Nesse sentido, o CPC/2015, com vigência a partir de março de 2016, além de repetir substancialmente os teores normativos dos artigos 481, $\S$ único, e 557, caput e $\S 1^{\circ}$, $475 \S 3^{\circ}, 543-\mathrm{A} \S 3^{\circ}$ e $543-\mathrm{B}$, todos do CPC reformado, nos seus artigos $949 \S$ único, 932, inciso IV, $496 \S 3^{\circ}, 1.035 \S 3^{\circ}$ e 1.036 , respectivamente, traz algumas novidades que reforçam a aproximação do Direito brasileiro ao commom law. Sobrelevam entre elas os dispositivos dos artigos 926 e 927, os quais instituem legalmente um sistema de precedentes, ao dispor que juízes e tribunais deverão observar as decisões do Supremo Tribunal Federal, em controle concentrado de constitucionalidade, os enunciados de súmulas vinculantes, os acórdãos em incidentes de assunção de competência ou de resolução de demandas repetitivas e em julgamento de recursos extraordinário e especial

18 MELlO, Patrícia Perrone Campos. Precedentes: o desenvolvimento judicial do direito no constitucionalismo contemporâneo. Rio de Janeiro: Renovar. 2008, p. 2-4. 
Rio de Janeiro. Ano 13. Volume 20. Número 3. Setembro a Dezembro de 2019

Periódico Quadrimestral da Pós-Graduação Stricto Sensu em Direito Processual da UERJ

Patrono: José Carlos Barbosa Moreira (in mem.). ISSN 1982-7636. pp. 187-215 www.redp.uerj.br

repetitivos. Também deverão ser observados pelos juízes e tribunais inferiores os enunciados das súmulas do Supremo Tribunal Federal em matéria constitucional e do Superior Tribunal de Justiça em matéria infraconstitucional, além da orientação do plenário ou do órgão especial aos quais estiverem vinculados.

Por óbvio, essa tendência de valorização dos pronunciamentos decisórios dos tribunais superiores como técnica de vinculação decisória repercute no recurso de agravo interno. Veja como isso ocorre.

\section{O RECURSO DE AGRAVO INTERNO NO NOVO CPC E SUA IMPORTÂNCIA PARA APLICAÇÃO DAS TÉCNICAS DO DISTINGUISHING E DO OVERRULING}

Agravo interno (art. 1.021 do CPC/2015) é o recurso cabível contra as decisões monocráticas, que são aquelas proferidas pelos relatores, Presidentes ou Vice-presidentes dos tribunais nos processos em curso perante os tribunais, tanto nos procedimentos recursais quanto nas demandas originárias. É também cabível agravo interno contra as decisões monocráticas que negarem seguimento a recursos especial ou extraordinário interpostos contra acórdãos que estejam em conformidade com entendimento dos tribunais superiores exarado em regime de repercussão geral ou de julgamento de recursos repetitivos (art. $1.030 \S 2^{\circ}$ do CPC/2015).

Quando o processo está em trâmite em algum tribunal, o que se espera que as decisões nele proferidas sejam colegiadas, por imperativo de seu juízo natural: a colegialidade. Mas acontece que é necessário autorizar que o relator profira decisões monocráticas (unipessoais) para dar andamento procedimental ao recurso, visando à sua apreciação pelo colegiado, ou para apreciar postulações das partes, tais como requerimento de tutela provisória nos recursos, declaração de inadmissibilidade de recurso que não preencha os requisitos legais de sua interposição e cabimento, homologar transação celebrada pelas partes.

Dierle Nunes, em artigo publicado no final do ano de 2007, sublinha a competência constitucional e, portanto, o juízo natural do colegiado para apreciação dos recursos, defendendo a estruturação do princípio constitucional da colegialidade, nos seguintes termos: “[...] o órgão jurisdicional competente para o julgamento dos recursos será sempre 
Revista Eletrônica de Direito Processual - REDP.

Rio de Janeiro. Ano 13. Volume 20. Número 3. Setembro a Dezembro de 2019

Periódico Quadrimestral da Pós-Graduação Stricto Sensu em Direito Processual da UERJ

Patrono: José Carlos Barbosa Moreira (in mem.). ISSN 1982-7636. pp. 187-215 www.redp.uerj.br

o colegiado, e não o juízo monocrático do relator". Porém, não é ilegal, nem inconstitucional a delegação de poderes aos relatores, a fim de que proferissem decisões monocráticas, desde que se viabilize a interposição de agravo interno contra os aludidos pronunciamentos decisórios ${ }^{19}$.

Assim, autoriza-se o proferimento de decisões monocráticas (unipessoais) quando o processo estiver tramitando nos tribunais, mas é assegurando às partes o direito de reexame e reversibilidade de tais atos decisórios pelo colegiado do tribunal, mediante o recurso de agravo interno.

A matriz normativa das decisões monocráticas é artigo 932 do CPC/2015, o qual estabelece as incumbências do relator nos processos em trâmite no tribunal. Não se pode olvidar, contudo, da norma do artigo 1.030, incisos I e II, também do CPC/2015.

Interessa mais de perto a este texto as decisões monocráticas (unipessoais) tomadas com base nos incisos IV e $\mathrm{V}$ do aludido dispositivo normativo, pois elas autorizam o relator a apreciar monocraticamente o mérito do recurso, negando-lhe ou dando-lhe provimento, isso com base em entendimento de jurisprudência dominante, sumular ou não, ou em entendimento firmado em julgamento de casos repetitivos, ou seja, aqueles pronunciamentos decisórios vinculantes ou precedentes obrigatórios. As decisões monocráticas referidas nos incisos I e II do artigo 1.030 também despertam atenção, devido ao fato de que autorizam a negativa de seguimento de recursos especial e extraordinário quando o acordão estiver em conformidade ao entendimento dos tribunais superiores em entendimento fixado em regime de repercussão geral ou recursos repetitivos, conforme o caso, ou autorizam a determinação de realização de juízo de retratação pelo juízo a quo quando o acordão recorrido for divergente de entendimento dos tribunais superiores nos casos de repercussão geral e recursos repetitivos, conforme o caso.

Inicialmente cumpre destacar que com o CPC/2015, em especial o seu artigo 1.021, fica encerrada a discussão a respeito de ser cabível ou não agravo interno contra essa ou aquela decisão monocrática. A partir da vigência do referido artigo, a regra que se extrai é que cabe agravo interno contra todas as decisões monocráticas (unipessoais) seja ela proferida pelo relator, ou em algumas hipóteses contra decisões proferidas por Presidente

\footnotetext{
${ }^{19}$ Colegialidade das decisões dos tribunais? Sua visualização como princípio constitucional e do Cabimento de interposição de agravo interno de todas as decisões monocráticas do relator. Revista IOB de Direito Civil e Processual Civil, v. 50, 2007, p. 52 e 58.
} 
Revista Eletrônica de Direito Processual - REDP.

Rio de Janeiro. Ano 13. Volume 20. Número 3. Setembro a Dezembro de 2019

Periódico Quadrimestral da Pós-Graduação Stricto Sensu em Direito Processual da UERJ

Patrono: José Carlos Barbosa Moreira (in mem.). ISSN 1982-7636. pp. 187-215 www.redp.uerj.br

ou Vice-Presidente de Tribunal, salvo expressa previsão legislativa em sentido contrário. Agora, o norte interpretativo é inverso ao do CPC/1973, pois neste o advogado tinha, muitas vezes, que procurar norma de previsão de cabimento do recurso em questão. Ao contrário do que ocorre no CPC/2015, uma vez que só não será cabível agravo interno de decisões monocráticas se a lei clara e expressamente classificar a decisão como irrecorrível $^{20}$. Por hipótese, a decisão a respeito da intervenção de amicus curiae (art. 138); a decisão que, fundada em justo motivo, releva a deserção e concede à parte prazo para realizar o preparo do recurso (art. $1.007 \S 6^{\circ}$ ), só para citar duas decisões monocráticas irrecorríveis no sistema recursal vigente.

A questão que precisa ser enfrentada e debatida, portanto, não é mais procurar um fundamento normativo para o cabimento de agravo interno com decisões monocráticas, máxime aquelas atinentes à admissibilidade de recursos, como fez Dierle Nunes, na vigência do CPC/1973 ${ }^{21}$. A necessidade agora é outra: chamar a atenção para a importância que o aludido recurso adquire no sistema normativo instituído pelo CPC/2015, uma vez que os incisos IV e V do artigo 932, assim como os incisos I e II do artigo 1.030 do mencionado código autorizam o relator, por meio de decisão monocrática, a apreciar o mérito do recurso, negar-lhe seguimento ou determinar a realização de juízo de retratação pelo juízo a quo quando houver algum provimento jurisdicional vinculante a respeito das questões debatidas no recurso. É aqui que mora o perigo!

O agravo interno, portanto, se coloca como um importante meio técnico, fundado no direito constitucional ao recurso, viabilizador de um espaço discursivo de construção, fiscalização e aplicação dos referidos provimento jurisdicionais vinculantes, em dinâmica de cooperação processual ${ }^{22}$.

Em razão disso, é absolutamente relevante que, ao se interpor agravo interno contra decisão monocrática, baseada nos incisos IV e V do artigo 932 e incisos I e II do artigo

\footnotetext{
${ }^{20}$ DIDIER Jr., Fredie; CUNHA, Leonardo Carneiro da. Curso de Direito Processual Civil - meios de impugnação às decisões judiciais e processos nos tribunais. Vol. 3 - 13 ${ }^{\mathrm{a}}$ ed. Salvador: Juspdodivm, 2016, p. 287-288; MACÊDO, Lucas Buril. Agravo interno: análise das modificações legais e de sua recepção no Superior Tribunal de Justiça. Revista de Processo (RePro) vol. 269, 2017, p. 313.

${ }^{21}$ Colegialidade das decisões dos tribunais? Sua visualização como princípio constitucional e do Cabimento de interposição de agravo interno de todas as decisões monocráticas do relator. Revista IOB de Direito Civil e Processual Civil, v. 50, 2007, p. 51-60.

${ }^{22}$ Acerca da cooperação processual consultar THEODORO JÚNIOR, Humberto; NUNES, Dierle; BAHIA, Alexandre Gustavo de Melo Franco; QUINAUD PEDRON, Flávio Barbosa. Novo CPC: fundamentos e sistematização $3^{\mathrm{a}}$ ed. Rio de Janeiro: Forense, 2016 p. 87-110.
} 
Rio de Janeiro. Ano 13. Volume 20. Número 3. Setembro a Dezembro de 2019

Periódico Quadrimestral da Pós-Graduação Stricto Sensu em Direito Processual da UERJ

Patrono: José Carlos Barbosa Moreira (in mem.). ISSN 1982-7636. pp. 187-215 www.redp.uerj.br

1.030 o recorrente perceba a necessidade de se trabalhar com analogias e contra analogias, similarmente ao que ocorre nos países do common law, eis que para se obter êxito em tal recurso deverá aplicar técnicas relativas ao sistema de precedentes judiciais: distinguishing (distinção) ou overruling (superação). A aplicação de tais técnicas exige árduo esforço argumentativo, ou como preferem Dierle Nunes e Aurélio Viana, renovado ônus argumentativo ${ }^{23}$. Caso contrário, haverá falsa aplicação de precedente, pois tal atividade dar-se-á de maneira (quase) "mecânica" e provavelmente o colegiado confirmará a decisão do relator, utilizando-se de um padrão decisório abstrato e distante das particularidades do caso, como se percebe na atualidade.

Isso devido ao fato de que se pretende estruturar normativamente sistema processual discursivo de aplicação de pronunciamentos decisórios vinculantes ou precedentes obrigatórios. Se o recurso de agravo interno não for capaz de estruturar espaço procedimental propiciador de aplicação e fiscalização discursiva de tais pronunciamentos, não restarão atendidas as exigências de legitimidade decisória e correção normativa imposta pela Constituição brasileira. Somente será possível controlar a aplicação dos aludidos pronunciamentos decisórios atacando a falibilidade normativa dos conteúdos justificadores (fundamentação) da decisão agravada, por meio da ampliação do discurso processual a respeito da aplicação ou não de entendimento firmados pelos tribunais superiores.

Soma-se a isso tudo o fato de que estudos empíricos (psicológicos e jurídicos) demonstram que magistrados, na verdade todos os seres humanos, sofrem propensões cognitivas, circunstância que os levam a buscar atalhos no exercício de suas funções - lei do menor esforço -, a fim de amenizar a pressão da incerteza e da exiguidade temporal presentes nos processos judiciais. Dessa forma, os magistrados ficariam menos propensos à mudança de entendimentos jurisprudenciais ou à ampliação do debate de questões na busca de formação mais sólida de pronunciamentos decisórios vinculantes ou precedentes, vez isso que exige um maior trabalho e elevada dedicação, de sorte a induzir o uso de ementas de acórdão ou enunciados sumulares, algo bem mais fácil e menos trabalhoso que a realização de sua superação ou distinção:

\footnotetext{
${ }^{23}$ VIANA, Antônio Aurélio de Souza, NUNES, Dierle José Coelho. Precedentes: a mutação do ônus argumentativo. Rio de Janeiro: Forense. 2018.
} 
Revista Eletrônica de Direito Processual - REDP.

Rio de Janeiro. Ano 13. Volume 20. Número 3. Setembro a Dezembro de 2019

Periódico Quadrimestral da Pós-Graduação Stricto Sensu em Direito Processual da UERJ

Patrono: José Carlos Barbosa Moreira (in mem.). ISSN 1982-7636. pp. 187-215

www.redp.uerj.br

Estudos empíricos (psicológicos e jurídicos), realizados com magistrados americanos, demonstram que o juiz sofre propensões cognitivas que o induzem a usar atalhos para ajudá-lo a lidar com a pressão da incerteza e do tempo inerentes ao processo judicial. É evidenciado que mesmo sendo experiente e bem treinado, sua vulnerabilidade a uma ilusão cognitiva no julgamento solitário influencia sua atuação. Um exemplo singelo encontrado nas pesquisas, que aclara esta situação, é a propensão do magistrado que indefere uma liminar a julgar, ao final, improcedente o pedido. Por um efeito de bloqueio ficou demonstrado que o juiz fica menos propenso à mudança de sua decisão mesmo à luz de novas informações ou depois de mais tempo para a reflexão. Tal bloqueio cognitivo ocorre por causa da tendência a querer justificar a alocação inicial de recursos (fuga ao retrabalho), confirmando que a decisão inicial estava correta. Tal constatação deve induzir o fomento ao debate como ferramenta de quebra das ilusões e propensões cognitivas. E aqui poderíamos ampliar no caso brasileiro para o uso de ementas de julgados e súmulas sem reflexão e como âncoras facilitadoras dos julgamentos, com o único sentido privado de otimizar numericamente o número de decisões. Faz-se uso de súmulas e "precedentes" sem a devida recuperação do(s) caso(s) paradigma(s), valendo-se apenas de ementas ou do pequeno texto das súmulas, como se uns e outros pudessem ter algum sentido sem aquilo (os casos) que lhes deram origem e se confundindo a ratio decidendi (fundamento determinante) com algum trecho da ementa ou do voto" ${ }^{24}$.

Portanto, fica fácil perceber que aquele que pretender afastar a aplicação de pronunciamento decisório vinculante ou precedente obrigatório, assumirá árduo ônus argumentativo, além de ter que compreender os contornos técnicos do distinguishing e do overruling. O fato de a legislação determinar que os tribunais uniformizem sua jurisprudência, além de mantê-la íntegra, estável e coerente não quer dizer apenas que os juízes devem seguir cegamente o conteúdo de decisões pretéritas. Ao contrário, isso, de igual maneira, inclui a possibilidade de superação (overruling) e distinção (distinguishing), porque nesses dois casos a história institucional da comunidade não é desprezada ${ }^{25}$.

\subsection{Noções acerca das técnicas do distinguishing e do overruling}

\footnotetext{
${ }^{24}$ NUNES, Dierle José Coelho; BAHIA, Alexandre Gustavo Melo Franco. Processo e República: uma relação necessária. Revista Brasileira de Direito Processual (Impresso), v. 88, 2014, p. 277-28-78.

25 BARBOZA, Estefânia Maria de Queiroz. Precedentes Judiciais e Segurança Jurídica: fundamentos e possibilidades para a jurisdição constitucional brasileira - São Paulo: Saraiva, 2014, p. 214-215.
} 
Revista Eletrônica de Direito Processual - REDP.

Rio de Janeiro. Ano 13. Volume 20. Número 3. Setembro a Dezembro de 2019

Periódico Quadrimestral da Pós-Graduação Stricto Sensu em Direito Processual da UERJ

Patrono: José Carlos Barbosa Moreira (in mem.). ISSN 1982-7636. pp. 187-215 www.redp.uerj.br

O overruling e o distinguishing são compreendidos como técnicas de não aplicação do precedente judicial, e permitem o desenvolvimento e a flexibilização do Direito jurisprudencial, além de ressaltar o caráter discursivo do sistema de precedentes judiciais.

O distinguishing é caracterizado pela existência de diferenças fáticas entre o caso que originou o precedente, prima facie aplicável, e o caso sub judice, ou a demonstração de que a ratio do precedente não se amolda ao caso sub judice, eis que as circunstâncias fáticas dos casos são diversas ${ }^{26}$.

A principal questão que se coloca nessa técnica é a categorização de fatos relevantes e irrelevantes, porque nem toda diferença é importante para que se concluir pela inaplicabilidade de um precedente. Obviamente, isso exige árdua e complexa atividade argumentativa dos participantes do processo ${ }^{27}$.

Marília Siqueira da Costa afirma que o distinguishing consiste na "técnica utilizada, para justificar a não aplicação do precedente judicial obrigatório, quando há distinção entre os elementos objetivos da demanda (a que ainda será decidida e aquela que deu origem ao precedente) ", após se constatar que as referidas demandas não são análogas, de modo a se autorizar o afastamento do precedente prima facie aplicável ${ }^{28}$.

Há duas maneiras de incidência do distinguishing: $a$ ) reconhecendo que ao caso sub judice não se aplica o precedente invocado, mediante o estabelecimento de uma exceção, anteriormente não reconhecida, aos fundamentos determinantes do precedente - exceção direta -, em decorrência de alguma particularidade do caso sub judice, o que, obviamente, exige fundamentação adequada (art. $489 \$ 1^{\circ}$, inciso VI, CPC/2015); $b$ ) estabelecimento de uma exceção indireta, que se caracteriza pela constatação de que há diferenças relevantes entre os casos, o que impõe e justifica a não aplicação do precedente aparentemente aplicável ${ }^{29}$.

\footnotetext{
${ }^{26}$ MARINONI, Luiz Guilherme. Precedentes obrigatórios. $2^{\text {a }}$ ed. São Paulo: Revista dos Tribunais. 2011, p. 327.

${ }^{27}$ PEIXOTO, Ravi. Superação do precedente e segurança jurídica. Salvador: Juspodivm, 2015, p. 214215.

${ }^{28}$ COSTA, Marília Siqueira. Noções fundamentais para o julgamento por aplicação do precedente judicial: necessidade de adaptação a partir do novo Código de Processo Civil. In: DIDIER JR, Fredie; MACÊDO, Lucas Buril de; FREIRE, Alexandre. (Org.). Novo CPC doutrina selecionada. 2ed.Salvador: Editora Juspodivm, 2015, v. 2, p, 832.

${ }^{29}$ BUSTAMANTE, Thomas da Rosa. Teoria do precedente judicial: a justificação e aplicação de regras jurisprudências. São Paulo: Noeses. 2012, p. 470-473. Marilia Siqueira da Costa acrescenta que "a primeira opção, denominada pelo autor de 'redução teleológica', consiste no estabelecimento, por razões de equidade, de uma exceção na hipótese de incidência do precedente judicial. Por outras palavras, com essa técnica, são
} 
Revista Eletrônica de Direito Processual - REDP.

Rio de Janeiro. Ano 13. Volume 20. Número 3. Setembro a Dezembro de 2019

Periódico Quadrimestral da Pós-Graduação Stricto Sensu em Direito Processual da UERJ

Patrono: José Carlos Barbosa Moreira (in mem.). ISSN 1982-7636. pp. 187-215

www.redp.uerj.br

Por essa rápida incursão na técnica do distinguishing (distinção) é fácil constatar

que sua adequada compreensão e aplicação requerem mudanças nas práticas processuais brasileira. Primeiro, mostra-se indispensável que se abandone a superficial e errônea prática de "aplicação (quase) "mecânica" de precedentes, mediante a limitadíssima "transcrição pura" de ementas de acórdãos, verbetes sumulares ou sínteses conclusivas de julgados dos tribunais brasileiros. E, pior, de maneira descontextualizada das particularidades fáticas do caso (demanda) que originou o precedente, prima facie aplicável, e de seus fundamentos determinantes ${ }^{30}$. O adequado uso da referida técnica reclama reconstrução do caso julgado pelo pronunciamento decisório vinculante ou precedente obrigatório, em suas particularidades fáticas e jurídicas (fundamentos determinantes) relevantes e não relevantes ${ }^{31}$.

Exige-se, por conseguinte, a inteligência de que o relatório, enquanto elemento essencial do pronunciamento decisório, tem no sistema normativo do CPC/2015 nova e importante função. É que não se pode compreender que o relatório se constitui apenas num requisito formal de validade do decisório, que se destina a identificar os elementos subjetivos e objetivas da demanda - partes, causa de pedir e pedido -, bem como apresentar, resumidamente, as principais ocorrências do processo (atos processuais realizados ou não realizados). Com o CPC/2015, o relatório, em decorrência da circunstância de que alguns pronunciamentos decisórios adquiriram extrema relevância para fundamentação das decisões judiciais, deverá expor de maneira clara todos os

reduzidas as situações de possível aplicação da norma jurídica. [...] Por meio da segunda técnica, conclui-se que os fatos que embasam a controvérsia não podem ser regulados pelo precedente que se pretende afastar. Ou seja, excluem-se aqueles fatos do âmbito de incidência das normas, mas não por inserir uma cláusula de exceção como na outra hipótese. Aqui, pretende-se demonstrar que não há possibilidade de inserir a situação do caso concreto na hipótese de incidência da norma, pois essa não era intenção da autoridade normativa. Para tanto, utiliza-se o raciocínio por interferência, que deverá concluir pela restrição da norma" (COSTA, Marília Siqueira. Noções fundamentais para o julgamento por aplicação do precedente judicial: necessidade de adaptação a partir do novo Código de Processo Civil. In: DIDIER JR, Fredie; MACÊDDO, Lucas Buril de; FREIRE, Alexandre. (Org.). Novo CPC doutrina selecionada. 2ed.Salvador: Editora Juspodivm, 2015, v. 2, p, 833-834).

${ }^{30}$ A propósito, ver estudo realizado por Alexandre Freitas Câmara, no qual foram analisados votos e decisões dos onze ministros do Supremo Tribunal Federal que (suspostamente) aplicaram precedentes. O estudo revela que a quase totalidade dos ministros se limitam a citar ementas de acórdãos ou enunciados sumulares, ou apenas a fazer menção ao número do recurso apreciado ou do procedimento do qual teria originado o precedente (CÂMARA, Alexandre Freitas. Levando os padrões decisórios a sério: formação e aplicação de precedentes e enunciados de súmula. São Paulo: Atlas. 2018, p. 145-175).

${ }^{31}$ NUNES, Dierle José Coelho; BAHIA, Alexandre Gustavo Melo Franco. Precedentes no CPC-2015: por uma compreensão constitucionalmente adequada de seu uso no Brasil. In: Alexandre Freire, Fredie Didier Jr., Lucas Buril de Macêdo e Ravi Medeiros Peixoto. (Org.). Coleção Novo CPC - Doutrina Selecionada - v.2 Processo de Conhecimento e Disposições finais transitórias. Salvador: Jus Podivm, 2015, v. 2, p. 723. 
Revista Eletrônica de Direito Processual - REDP.

Rio de Janeiro. Ano 13. Volume 20. Número 3. Setembro a Dezembro de 2019

Periódico Quadrimestral da Pós-Graduação Stricto Sensu em Direito Processual da UERJ

Patrono: José Carlos Barbosa Moreira (in mem.). ISSN 1982-7636. pp. 187-215

www.redp.uerj.br

argumentos fáticos e jurídicos identificadores do caso, a fim de que possam ser levados em consideração por todos os membros do colegiado (não só pelo relator), em primeiro lugar.

E depois, pela comunidade jurídica, de modo a viabilizar a identificação dos fundamentos determinantes (ratio decidendi) do pronunciamento decisório invocado como precedente ${ }^{32}$.

É necessário que essas premissas sejam observadas, a fim de que a complexa técnica do distinguishing (distinção) venha a ser adequadamente aplicada no Brasil, possibilitando indispensável controle e fiscalização de aplicação dos conteúdos dos pronunciamentos decisórios ou precedentes obrigatórios.

É aqui que entra em cena o agravo interno interposto contra decisões monocráticas fundamentadas em padrões decisórios considerados vinculantes ou obrigatórios.

Nessas situações, ao se interpor agravo interno, o agravante, para obter êxito em seu recurso, a ser apreciado pelo órgão colegiado, deve ter como objetivo demonstrar a existência de distinção entre o caso sub judice e o caso que deu origem ao pronunciamento decisório invocado como precedente para justificar a decisão recorrida. Para tanto, caberá ao recorrente apontar as circunstâncias fáticas relevantes que diferenciam os casos exceção indireta -; ou as circunstâncias especiais presentes no caso sub judice e não consideradas no caso paradigma capazes de justificar a não aplicação do pronunciamento decisório utilizado como precedente - exceção direta.

Para se demonstrar a existência de distinção entre os casos deverá o agravante apontar as diferenças relevantes entre eles, o que requer a transcrição ou reconstrução de

\footnotetext{
${ }^{32}$ NUNES, Dierle José Coelho. Colegialidade Corretiva e CPC-2015. In: Fredie Didier Jr., Lucas Buril de Macêdo, Ravi Peixoto, Alexandre Freire. (Org.). Coleção Novo CPC - Doutrina Selecionada - processos nos tribunais e meios de impugnação às decisões judiciais. 2ed.Salvador: Jus Podivm, 2016, v. 6, p. 41-42. Importante ressaltar que essa mudança de função do relatório, decorrente do dever de fundamentação estruturada (ou exauriente) dos atos decisório, traz como consequência para os advogados das partes e os membros no Ministério Público a exigência de se levar em consideração o conteúdo dos pronunciamentos decisórios vinculantes ou precedentes já na petição inicial. E ao fazê-lo, deve-se, de igual maneira ao reclamado dos magistrados, reconstruir os elementos fáticos do caso que originou o mencionado pronunciamento decisório, além de se explicitar os fundamentos determinantes para a conclusão da decisão. Logo, ao se expor a causa de pedir, o seu subscritor, quando invocar algum dos pronunciamentos decisórios do artigo 972, precisa reconstruí-lo adequadamente, evitando a equivocada prática de "citação de longas ementas de julgados que não são correlacionadas com a pretensão articulada pelo autor, ou são dissociadas da situação fática que lhe é subjacente". Isso pelo fato que as partes não podem deixar todo o fardo argumentativo de aplicação das técnicas do distinguishing e do overruling nas costas dos magistrados PINHEIRO, Guilherme César. O Novo Código de Processo Civil e as alterações não explícitas sobre a petição inicial. Revista de Processo, v. 258 2016, p. 94-95; PINHEIRO, Guilherme César. O novo Código de Processo Civil e as alterações não explícitas sobre a petição inicial. In: ARRUDA ALVIM, Teresa; DIDIER Jr., Fredie. (Org.). Doutrinas Essenciais - Novo Processo Civil. 2ed. São Paulo: Revista dos Tribunais, 2018, Vol. IV, p. 63-64).
} 
Rio de Janeiro. Ano 13. Volume 20. Número 3. Setembro a Dezembro de 2019

Periódico Quadrimestral da Pós-Graduação Stricto Sensu em Direito Processual da UERJ

Patrono: José Carlos Barbosa Moreira (in mem.). ISSN 1982-7636. pp. 187-215 www.redp.uerj.br

trechos do relatório e do voto dos dois (ou mais) casos. Isso é o que se tem chamado de confronto ou cotejo analítico. Tradicionalmente, exige-se dos recorrentes a realização de confronto ou cotejo analítico para demonstrar a similitude de casos expressos em acórdãos paradigma e recorrido, quando da interposição de recurso especial fundado em dissídio jurisprudencial (art. $\left.1.029 \S 1^{\circ}, \mathrm{CPC} / 2015\right)$ e de embargos de divergência (art. $1.043 \S 1^{\circ} \mathrm{do}$ CPC/2015). Acontece que no caso do agravo interno deverá ser demonstrado a existência de diferenças relevantes entre os casos, mediante o mesmo confronto ou cotejo analítico, só que inverso ou invertido - cotejo analítico inverso ou invertido.

Mas não é só. Passar a ser necessário, de igual maneira, trabalhar com a técnica do overruling quando da interposição de agravo interno contra decisão monocrática proferida com fundamento em padrões decisórios.

O overruling consiste na revogação do precedente, substituindo-o por outro que seja considerado melhor, quando o conteúdo da decisão pretérita se constitua num erro jurídico. Aqui, um precedente é negado para que o Direito seja confirmado ${ }^{33}$.

Segundo Marília Siqueira da Costa, o overruling (superação) "é, pois de técnica utilizada, nos países de tradição de common law, para retirar a força vinculante do precedente judicial, substituindo por outro. Trata-se de uma rejeição da tese jurídica contida no precedente, por considerá-la ultrapassada ou equivocada, substituindo-a por uma outra orientação". Em seguida, a autora conclui que pelo uso da aludida técnica tornase possível "reconhecer a existência de uma razão jurídica para o abandono da tese anteriormente aplicada. Por meio desta técnica, portanto, haverá uma desconstrução do posicionamento acerca da questão de direito que envolve a controvérsia"34.

No caso do overruling, o que se faz é demonstrar que o precedente afastado não tem mais aplicação e deve ser substituído por outra ratio decidenti, porque se tornou juridicamente inconsistente. Com essa técnica busca-se a correção do ordenamento jurídico.

Essas duas técnicas reforçam o caráter discursivo do sistema de precedentes judiciais e evidenciam que tal sistema tem como base a racionalidade argumentativa, e não

\footnotetext{
${ }^{33}$ BARBOZA, Estefânia Maria de Queiroz. Precedentes Judiciais e Segurança Jurídica: fundamentos e possibilidades para a jurisdição constitucional brasileira - São Paulo: Saraiva, 2014, p. 229-230.

${ }^{34}$ COSTA, Marília Siqueira. Noções fundamentais para o julgamento por aplicação do precedente judicial: necessidade de adaptação a partir do novo Código de Processo Civil. In: DIDIER JR, Fredie; MACÊDO, Lucas Buril de; FREIRE, Alexandre. (Org.). Novo CPC doutrina selecionada. 2ed.Salvador: Editora Juspodivm, 2015, v. 2, p, 837.
} 
Revista Eletrônica de Direito Processual - REDP.

Rio de Janeiro. Ano 13. Volume 20. Número 3. Setembro a Dezembro de 2019

Periódico Quadrimestral da Pós-Graduação Stricto Sensu em Direito Processual da UERJ

Patrono: José Carlos Barbosa Moreira (in mem.). ISSN 1982-7636. pp. 187-215 www.redp.uerj.br

a autoridade de Tribunais Superiores ${ }^{35}$. Elas [as técnicas do distinguishing e do overruling] hão de ser compreendidas como mecanismos de controle das decisões do Tribunais Superiores, de maneira que fique afastada a arbitrariedade desses pronunciamentos decisórios. Não podem, de forma alguma, serem vistas como abertura discricionária para a não aplicação de precedentes.

Isso devido à circunstância de que o CPC/2015 apresenta perfil comparticipativo ou de cooperação processual, no interior do qual são afastados qualquer foco de centralidade ou protagonismo, seja das partes (e de seus procuradores), seja dos magistrados (protagonismo judicial). Além do mais, a novel legislação propicia a estruturação teórica e técnica de "uma comunidade de trabalho" na qual os sujeitos processuais atuam de maneira interdependente e se fiscalizam, reciprocamente, na construção e efetivação das decisões judiciais ${ }^{36}$.

Salienta-se que os principais fundamentos da cooperação processual são o princípio do contraditório, como garantia de influência e não surpresa, e o policentrismo processual, os quais visam, sobremaneira, à quebra do indesejado e constitucionalmente inadequado protagonismo judicial, sem, contudo, abrir qualquer possibilidade de retorno ao liberalismo $\operatorname{processual}^{37}$.

Essas enunciações teóricas permitem seja rechaçada a visão estatista e centralizadora, defendida por Luiz Guilherme Marinoni e Daniel Mitidiero, de que caberia apenas ao Supremos Tribunal Federal e ao Superior Tribunal de Justiça, compreendido como "Cortes Supremas" 38 , a formação de precedentes judiciais, de modo que aos tribunais

\footnotetext{
${ }^{35}$ BUSTAMANTE, Thomas da Rosa. Teoria do precedente judicial: a justificação e aplicação de regras jurisprudências. São Paulo: Noeses. 2012, p. 395.

36 THEODORO JÚNIOR, Humberto; NUNES, Dierle; BAHIA, Alexandre Gustavo de Melo Franco; QUINAUD PEDRON, Flávio Barbosa. Novo CPC: fundamentos e sistematização $2^{a}$ ed. Rio de Janeiro: Forense, 2015, p. 69-100.

37 NUNES, Dierle José Coelho. Processo jurisdicional democrático: uma análise crítica das reformas processuais. Curitiba: Juruá, 2009, p. 177-251.

38 Daniel Mitidiero defende a tese de que tanto o STF quanto o STJ funcionariam como Cortes Supremas, e não como Cortes Superiores. É que, segundo o autor, a corte superior, no modelo de corte de vértice da organização judiciária, desempenha a função de controlar a legalidade das decisões proferidas pelos juízos ordinários, mediante a apreciação de recursos interpostos pelas partes, permitindo seja definida a exata interpretação da lei e a formação de jurisprudência uniforme, após a reiteração de decisões pela corte superior, as quais produzem efeitos inter partes. Por outro lado, as cortes supremas desempenham a função de orientar a justa interpretação da ordem jurídica, de conferir unidade ao Direito, e suas decisões vinculam a sociedade civil e todos os órgãos do Judiciário (MITIDIERO, Daniel. Cortes Superiores e Cortes Supremas: do controle à, da Jurisprudência ao Precedente. $2^{a}$ ed. São Paulo: Revista dos Tribunais. 2014, p. 35-80). Em razão disso, é que tanto o STF quanto o STJ seriam cortes de precedentes, cujas decisões seriam proativas, e não cortes de controle cujas decisões são reativa (MARINONI Luiz Guilherme, O STJ enquanto
} 
Revista Eletrônica de Direito Processual - REDP.

Rio de Janeiro. Ano 13. Volume 20. Número 3. Setembro a Dezembro de 2019

Periódico Quadrimestral da Pós-Graduação Stricto Sensu em Direito Processual da UERJ

Patrono: José Carlos Barbosa Moreira (in mem.). ISSN 1982-7636. pp. 187-215 www.redp.uerj.br

inferiores e aos juízos de primeira instância incumbiriam apenas solução do caso concreto $^{39}$.

Para tanto, é indispensável que se adote como marco de reflexão a compreensão de contraditório como garantia de influência e não surpresa (arts. $7^{\circ}, 9^{\circ}$ e 10 do Novo CPC), base normativa para a implementação do sistema de cooperação processual $\left(\operatorname{art.~} 6^{\circ}\right.$ ), adotado pelo CPC/2015.

Com efeito, as partes e os juízes de primeira instância e tribunais inferiores são vistos como importantes interlocutores com os Tribunais Superiores, a quem cabe prioritariamente, mas não exclusivamente - a formação de precedentes obrigatórios ou pronunciamentos decisórios vinculantes. A finalidade dessa interlocução é permitir constante aprimoramento do Direito, pois a necessidade de respeito aos precedentes não significa adesão mecânica a eles, muito menos impossibilidade de se instaurar divergência jurídica sobre seu conteúdo, visando à melhoria do sistema jurídico. Por óbvio, que tal postura depende de fundamentação estruturada ou exauriente do ato decisório, construída de forma participada pelos partícipes do processo $^{40}$.

Salienta-se que a não aplicação de um precedente, seja pela superação, seja pela distinção, não induz, necessariamente, ao desrespeito à integridade do Direito.

Integridade não significa somente decidir casos semelhantes de igual maneira, isto é coerência: aplicar os mesmos princípios a "casos idênticos", de modo que o Judiciário lhes confira igual consideração e respeito. A integridade é mais que isso: ela exige que os juízes construam seus argumentos de forma integrada ao Direito e respeite a história institucional da comunidade de princípios, constituindo-se como garantia contra a arbitrariedade e o voluntarismo na atividade interpretativa do ordenamento jurídico. Com isso, a integridade

corte de precedentes: recompreensão do sistema processual da corte suprema. $2^{\text {a }}$. Ed. São Paulo: Revista dos Tribunais. 2014). Antônio Aurélio de Souza Viana apresenta interessante crítica as propostas ofertadas por Marinoni e Mitidiero, conferir: Precedentes vinculantes e as cortes supremas: uma análise crítica. Teoria jurídica contemporânea, v. 2, p. 122-146, 2017).

39 MARINONI, Luiz Guilherme. O STJ enquanto corte de precedentes: recompreensão do sistema processual da corte suprema. 2. ed. São Paulo: Revista dos Tribunais, 2014, p. 128-129 e 155; MITIDIERO, Daniel. Cortes Superiores e Cortes Supremas: do controle à, da Jurisprudência ao Precedente. $2^{\mathrm{a}}$ ed. São Paulo: Revista dos Tribunais. 2014, p. 55-130.

40 THEODORO JÚNIOR, Humberto; NUNES, Dierle; BAHIA, Alexandre Gustavo de Melo Franco; QUINAUD PEDRON, Flávio Barbosa. Novo CPC: fundamentos e sistematização $2^{\mathrm{a}}$ ed. Rio de Janeiro: Forense, 2015, p. 137-138. 
Revista Eletrônica de Direito Processual - REDP.

Rio de Janeiro. Ano 13. Volume 20. Número 3. Setembro a Dezembro de 2019

Periódico Quadrimestral da Pós-Graduação Stricto Sensu em Direito Processual da UERJ

Patrono: José Carlos Barbosa Moreira (in mem.). ISSN 1982-7636. pp. 187-215 www.redp.uerj.br

permite a quebra da coerência ao autorizar a não aplicação de um precedente (decisão) quando este se mostrar contrário à Constituição ${ }^{41}$.

Nessa linha de reflexão, não se pode ignorar que um sistema de observância de pronunciamentos decisórios vinculantes ou precedentes obrigatórios que se pretenda discursivo reclama a oferta de sistema recursal fluído e que garanta o acesso aos Tribunais Superiores. O instituto do recurso, enquanto garantia constitucional de exercício do contraditório e da ampla defesa, além de possibilitar a revisibilidade, análise e reanálise pelo juízo ad quem das questões objeto de discussão contraditorial pelas partes, apreciadas ou não pelo juízo $a q u o^{42}$, é instrumento técnico que viabiliza o debate panorâmico das formação das decisões que originam os precedentes do artigo 927 do Novo CPC ${ }^{43}$.

Acrescenta-se que no caso de overruling, o acesso aos Tribunais Superiores é de acentuada relevância, haja vista que em ordenamentos jurídicos tradicionalmente vinculados ao common law somente o tribunal que proferiu a decisão que dá origem ao precedente pode revogá-1o ${ }^{44}$. É em razão disso tudo que um sistema de precedente precisa caminhar lado a lado com um sistema recursal fluído e garantidor de acesso aos Tribunais Superiores e seus respectivos colegiados. Não é constitucionalmente adequado importar a cultura dos Estados Unidos e Inglaterra, onde a Suprema Corte e Câmara dos Lordes escolhem, discricionariamente, quantos e quais os recursos apreciarão, como apregoado por Gustavo Nogueira ${ }^{45}$. O restrito (ou quase impossível) acesso aos tribunais superiores acabará induzindo o uso da técnica do anticipatory overruling (superação antecipação), consistente em não aplicação, por tribunal inferior, de precedente vinculante de Tribunal Superior, invocado por alguma parte ${ }^{46}$.

\footnotetext{
${ }^{41}$ STRECK, Lênio Luiz. O Novo CPC terá mecanismos para combater decisionismos e arbitrariedades? Coluna Senso Incomum, publicação em 18 de dezembro de 2014. Disponível em: http://www.conjur.com.br/2014-dez-18/senso-incomum-cpc-mecanismos-combater-decisionismosarbitrariedades

${ }^{42}$ NUNES, Dierle José Coelho. Direito constitucional ao recurso: da teoria geral dos recursos, das reformas processuais e da comparticipação nas decisões. Rio de Janeiro: Lumen Juris, 2006, p. 168.

${ }^{43}$ NUNES, Dierle José Coelho; BAHIA, Alexandre Gustavo Melo Franco; CÂMARA, Bernardo Ribeiro; SOARES, Carlos Henrique. Curso de Direito Processual Civil: fundamentação e aplicação. 2a. ed. Belo Horizonte: Fórum, 2013, p. 266.

${ }^{44}$ PEIXOTO, Ravi. Superação do precedente e segurança jurídica. Salvador: Juspodivm, 2015, p. 197198.

${ }^{45}$ NOGUEIRA, Gustavo Santana. Precedentes vinculantes no direito comparado e brasileiro. $2^{\mathrm{a}}$ ed. Salvador: Jus Podivm, 2013, p. 238-240.

${ }^{46}$ PEIXOTO, Ravi. Superação do precedente e segurança jurídica. Salvador: Juspodivm, 2015, p. 231.
} 


\section{CONCLUSÃO}

A partir do que foi exposto nas linhas anteriores, tem-se a intenção de provocar a comunidade jurídica a compreender a importância que o recurso de agravo interno ganhou no CPC/2015, seja em decorrência de sua regulamentação unificadora no artigo 1.021, seja, sobremaneira, pela sua relação com a aplicação das técnicas do distinguishing e do overruling.

O que se pretende destacar é que não basta simplesmente ofertar a possibilidade de interpor recurso contra as decisões monocráticas (unipessoais). É de extrema relevância, por imperativo constitucional, que a compreensão do instituto recursal e do ato decisório de apreciação do recurso sejam adequados ao marco do Estado Democrático de Direito.

É nesse contexto que se chama a atenção da comunidade jurídica que com o CPC/2015, compreendido como produto de um processo de constitucionalização do Direito brasileiro e redemocratização da sociedade brasileira, a compreensão de recurso não pode ser limitada a meio técnico de que as partes dispõem para manifestar seu natural inconformismo com a decisão judicial que lhe é adversa. Recurso é direito constitucional que viabiliza à correção normativa das decisões judiciais, a partir de um espaço técnico procedimental discursivo de apontamentos de erros jurídicos existentes nos fundamentos ou no procedimento encaminhador das decisões recorridas - ataque às falibilidades -, espaço esse criado pelo contraditório e ampla defesa, que são, de igual modo, fatores de legitimidade democrática de exercício da atividade jurisdicional.

Tal compreensão se coloca como premissa básica para que as técnicas do distinguishing e do overruling sejam aplicadas corretamente dentro de um sistema discursivo de construção e controle de aplicação de pronunciamentos decisórios vinculantes ou precedentes obrigatórios, de modo a acabar com as equivocadas práticas de "aplicação (quase) mecânica de precedente à brasileira", limitada a transcrições pura de ementas, súmulas ou sínteses conclusivas de decisões, sobretudo as colegiadas.

\section{REFERÊNCIAS}

ASSIS, Araken de. Manual dos Recursos. $6^{\text {a }}$. ed. São Paulo: Editora Revista dos Tribunais, 2014. 
Rio de Janeiro. Ano 13. Volume 20. Número 3. Setembro a Dezembro de 2019

Periódico Quadrimestral da Pós-Graduação Stricto Sensu em Direito Processual da UERJ

Patrono: José Carlos Barbosa Moreira (in mem.). ISSN 1982-7636. pp. 187-215 www.redp.uerj.br

BARACHO, José Alfredo de Oliveira. Teoria geral do processo constitucional. Revista da

Faculdade Mineira de Direito, Belo Horizonte, v. 2, n. 3 e 4, p. 89-154, $1^{\circ}$ e $2^{\circ}$ sem. 1999.

BARACHO, José Alfredo de Oliveira. Direito processual constitucional: aspectos contemporâneos. Belo Horizonte: Fórum, 2008;

BARBOZA, Estefânia Maria de Queiroz. Precedentes Judiciais e Segurança Jurídica: fundamentos e possibilidades para a jurisdição constitucional brasileira - Livro impresso. 1. ed. São Paulo: Saraiva, 2014.

BARROS, Flaviane de Magalhães; NUNES, Dierle José Coelho. As reformas processuais macroestruturais brasileiras. In: BARROS, Flaviane de Magalhães; MORAIS, José Luis bolzan. (Org.). Reforma do processo civil: perspectivas constitucionais. Belo Horizonte: Forum, 2010, p. 17-28.

BRÊTAS C. Dias, Ronaldo. As reformas do Código de Processo Civl e o modelo constitucional do processo. In: BRÊTAS C. DIAS, Ronaldo; NEPOMUCENO, Luciana Diniz (Org.). Processo Civil Reformado. $2^{\mathrm{a}}$ ed. Belo Horizonte: Del Rey, 2009, p. 457-496.

BRÊTAS C. DIAS, Ronaldo. Processo constitucional e estado democrático de direito. $3^{a}$ Edição Belo Horizonte: Del Rey. 2015.

BRÊTAS C. DIAS, Ronaldo; SOARES, Carlos Henrique; MARQUES BRÊTAS, Suzana Oliveira; DIAS, Renato José Barbosa; BRÊTAS Yvonne Mól. Estudo Sistemático do NCPC. $2^{\mathrm{a}}$ ed. D'PLÁCIO Editora. Belo Horizonte 2016.

BUSTAMANTE, Thomas da Rosa. Teoria do precedente judicial: a justificação e aplicação de regras jurisprudências. São Paulo: Noeses. 2012.

CÂMARA, Alexandre Freitas. Levando os padrões decisórios a sério: formação e aplicação de precedentes e enunciados de súmula. São Paulo: Atlas. 2018.

CATTONI DE OlIVEIRA, Marcelo Andrade. Processo Constitucional. 3. ed. Belo Horizonte: Editora Fórum, 2016.

COSTA, Marília Siqueira. Noções fundamentais para o julgamento por aplicação do precedente judicial: necessidade de adaptação a partir do novo Código de Processo Civil. In: DIDIER JR, Fredie; MACÊDO, Lucas Buril de; FREIRE, Alexandre. (Org.). Novo CPC doutrina selecionada. 2ed.Salvador: Editora Juspodivm, 2015, v. $2, \mathrm{p}, 817-846$. 
DIDIER Jr., Fredie; CUNHA, Leonardo Carneiro da. Curso de Direito Processual Civil meios de impugnação às decisões judiciais e processos nos tribunais. Vol. $3-13^{\mathrm{a}}$ ed. Salvador: Juspdodivm, 2016.

LEAL, André Cordeiro. Inconsistências do direito ao recurso como meio de acesso ao duplo grau de jurisdição. In: CASTRO, João Antônio de Lima; FREITAS, Sérgio Henriques Zandona. (Org.). Direito Processual - Estudo da Processualidade Jurídica Constitucionalizada. 1ed.Belo Horizonte: PUC MINAS - Instituto de Educação Continuada, 2012, p. 337-347.

LEAL, André Cordeiro. Instrumentalidade do processo em crise. Belo Horizonte: Mandamentos, 2008.

MACÊDO, Lucas Buril. Agravo interno: análise das modificações legais e de sua recepção no Superior Tribunal de Justiça. Revista de Processo (RePro) vol. 269, 2017, p. 311327.

MARINONI, Luiz Guilherme. Precedentes obrigatórios. $2^{\mathrm{a}}$ ed. São Paulo: Revista dos Tribunais. 2011.

MARINONI, Luiz Guilherme. O STJ enquanto corte de precedentes: recompreensão do sistema processual da corte suprema. 2. ed. São Paulo: Revista dos Tribunais, 2014.

MARINONI, Luiz Guilherme, A Eticidade dos precedentes: a justificativa do Novo CPC. São Paulo: Revista dos Tribunais, 2015.

MELLO, Patrícia Perrone Campos. Precedentes: o desenvolvimento judicial do direito no constitucionalismo contemporâneo. Rio de Janeiro: Renovar. 2008.

MITIDIERO, Daniel. Cortes Superiores e Cortes Supremas: do controle à, da Jurisprudência ao Precedente. $2^{\mathrm{a}}$ ed. São Paulo: Revista dos Tribunais. 2014.

NOGUEIRA, Gustavo Santana. Precedentes vinculantes no direito comparado e brasileiro. $2^{\mathrm{a}}$ ed. Salvador: Jus Podivm, 2013.

NUNES, Dierle José Coelho. Direito constitucional ao recurso: da teoria geral dos recursos, das reformas processuais e da comparticipação nas decisões. Rio de Janeiro: Lumen Juris, 2006.

NUNES, Dierle José Coelho. Colegialidade das decisões dos tribunais? Sua visualização como princípio constitucional e do Cabimento de interposição de agravo interno de todas as decisões monocráticas do relator. Revista IOB de Direito Civil e Processual Civil, v. 50, p. 50-61, 2007. 
Rio de Janeiro. Ano 13. Volume 20. Número 3. Setembro a Dezembro de 2019 Periódico Quadrimestral da Pós-Graduação Stricto Sensu em Direito Processual da UERJ

Patrono: José Carlos Barbosa Moreira (in mem.). ISSN 1982-7636. pp. 187-215 www.redp.uerj.br

NUNES, Dierle José Coelho. Processo jurisdicional democrático: uma análise crítica das reformas processuais. Curitiba: Juruá, 2009.

NUNES, Dierle José Coelho; BAHIA, Alexandre Gustavo Melo Franco; CÂMARA, Bernardo Ribeiro; SOARES, Carlos Henrique. Curso de Direito Processual Civil: fundamentação e aplicação. 2a. ed. Belo Horizonte: Fórum, 2013.

NUNES, Dierle José Coelho; BAHIA, Alexandre Gustavo Melo Franco. Processo e República: uma relação necessária. Revista Brasileira de Direito Processual (Impresso), v. 88, p. 275-281, 2014.

NUNES, Dierle José Coelho; STRECK, Lênio Luiz. O Senado vai permitir a mutilação do novo CPC antes de entrar em vigor. Consultor Jurídico (São Paulo. Online), v. 1122015, p. 1-5, 2015.

NUNES, Dierle José Coelho. Colegialidade Corretiva e CPC-2015. In: Fredie Didier Jr., Lucas Buril de Macêdo, Ravi Peixoto, Alexandre Freire. (Org.). Coleção Novo CPC - Doutrina Selecionada - processos nos tribunais e meios de impugnação às decisões judiciais. 2ed.Salvador: Jus Podivm, 2016, v. 6, p. 33-54.

NUNES, Dierle José Coelho; BAHIA, Alexandre Gustavo Melo Franco. Precedentes no CPC-2015: por uma compreensão constitucionalmente adequada de seu uso no Brasil. In: Alexandre Freire, Fredie Didier Jr., Lucas Buril de Macêdo e Ravi Medeiros Peixoto. (Org.). Coleção Novo CPC - Doutrina Selecionada - v.2 Processo de Conhecimento e Disposições finais transitórias. 1ed.Salvador: Jus Podivm, 2015, v. 2, p. 719-756.

NUNES, Dierle José Coelho ; VIANA, Antônio Aurélio de Souza. . Ônus da dialeticidade: nova 'jurisprudência defensiva' no STJ? Consultor Jurídico (Conjur) (SÃO PAULO. ONLINE), v. 15052017, p. 1-5, 2017.

PEIXOTO, Ravi. Superação do precedente e segurança jurídica. Salvador: Juspodivm, 2015.

PINHEIRO, Guilherme César. A Vinculação Decisória no Estado Democrático de Direito: por uma compreensão constitucionalmente adequada da aplicação de precedentes, súmulas e decisões vinculantes. Rio de Janeiro: Lumen Juris, 2016 (a).

PINHEIRO, Guilherme César. O Novo Código de Processo Civil e as alterações não explícitas sobre a petição inicial. Revista de Processo, v. 258, p. 85-101, 2016 (b).

PINHEIRO, Guilherme César; SANTOS JUNIOR, Waldir Miguel. O princípio 
constitucional da presunção de inocência e o Projeto de Novo Código de Processo

Penal. Revista eletrônica de direito processual, 2017. v. 18, p. 175-197.

PINHEIRO, Guilherme César. O novo Código de Processo Civil e as alterações não explícitas sobre a petição inicial. In: ARRUDA ALVIM, Teresa; DIDIER Jr., Fredie. (Org.). Doutrinas Essenciais - Novo Processo Civil. 2ed. São Paulo: Revista dos Tribunais, 2018, Vol. IV, p. 51-68.

STRECK, Lênio Luiz. O Novo CPC terá mecanismos para combater decisionismos e arbitrariedades? Coluna Senso Incomum, publicação em 18 de dezembro de 2014. Disponível em: http://www.conjur.com.br/2014-dez-18/senso-incomum-cpcmecanismos-combater-decisionismos-arbitrariedades

THEODORO JÚNIOR, Humberto; NUNES, Dierle; BAHIA, Alexandre Gustavo de Melo Franco; QUINAUD PEDRON, Flávio Barbosa. Novo CPC: fundamentos e sistematização: Revista, Atualizada e Ampliada. 2. ed. Rio de Janeiro: Forense, 2015. Novo CPC: fundamentos e sistematização: Revista, Atualizada e Ampliada. 3. ed. Rio de Janeiro: Forense, 2016. VIANA, Antônio Aurélio de Souza. Precedentes vinculantes e as cortes supremas: uma análise crítica. Teoria jurídica contemporânea, v. 2, p. 122-146, 2017.

Viana, Antônio Aurélio de Souza, NUNES, Dierle José Coelho. Precedentes: a mutação do ônus argumentativo. Rio de Janeiro: Forense. 2018. 